\title{
THIRTY YEARS OF EPIDEMIOLOGICAL STUDIES OF CARDIOVASCULAR DISEASE RISK FACTORS IN LATVIA: WHY ARE THEY NEEDED?
}

\author{
Pēteris Apinis ${ }^{1}$, Vilnis Dzērve ${ }^{2, \#}$, Anda Čakša ${ }^{3}$, Iveta Bajāre ${ }^{2,3}$, and Andrejs Ërglis ${ }^{2,3}$ \\ ${ }^{1}$ Latvian Medical Association, 3 Skolas Str., Rīga, LV-1010, LATVIA \\ ${ }^{2}$ Institute of Cardiology and Regenerative Medicine, 13 Pilsoṇu Str., Rīga, LV-1002, LATVIA \\ ${ }^{3}$ Faculty of Medicine, University of Latvia, 3 Jelgavas Str., Rīga, LV-1004, LATVIA \\ \# Corresponding author, e-mail: vilnisdzerve @ inbox.lv
}

Contributed by Andrejs Ërglis

\begin{abstract}
The present review is designed to provide insight into population-based investigations of cardiovascular risk factors in Latvia. Most of them represent urban, rural and mixed populations. The results are age-standardised using the European Standard Population. All of the studies confirm a high prevalence of cardiovascular risk factors with wide differences across the studies. The differences are not consistent or regular and some of the underlying reasons are discussed. Analysis of the previous studies justifies the need for a nationwide cross-sectional epidemiological study, which in a small country can be carried out in compliance with all the requirements for a population-based epidemiological study.
\end{abstract}

Key words: cardiovascular risk factors, primary prevention, population based epidemiological surveys.

\section{INTRODUCTION}

It is well-known that non-communicable diseases (NCDs) exceed communicable diseases in causing mortality and disability in most countries. Globally, NCDs are responsible for $73 \%$ of deaths (Roth et al., 2018) and have appropriately gained recognition over the past 20 years as a major global public health concern. In 2011, WHO member states signed up to the $25 \times 25$ initiative, a plan to cut mortality due to non-communicable diseases by $25 \%$ by 2025 (Anonymous, 2020a).

There are a number of challenges for health policymakers to reach this goal in Latvia.

Firstly, the health industry does not generate money the way economists and financial people are used to see it. As a result, in the discussions about investing to show the benefits to the economy, the economic reasons do not suffice to describe diagnoses, emotions, pain and suffering. This requires fully accurate and clear data that shows the best short and long-term investment in a language that both parties can understand.
Secondly, in the health sector, there is no single answer to the difficult question of what should be done or where to invest first. It is a complex and continuously dynamically changing system that can be understood by keeping track of dynamics data. It is necessary to watch trends, reacting proactively to them, but, more importantly, to detect possible future challenges to be prepared for before they happen.

The policy must have the ability to anticipate future events in order to prepare programmes and human resources for these future events.

Thirdly, the data must be perceived as a motivation booster for "promoting" public health. Public opinion polls show that $73 \%$ of the Latvian society agree that finances should be focused on medicine as a priority (Anonymous, 2029). However, data on eliminating risk factors $(\mathrm{RF})$ in their daily lives and changing behaviours at the level of each individual are far below these figures.

Fourthly, research in neurosciences shows that brain function tends to accept the easiest solution, and the hardest, most difficult ones are bypassed. There is a great desire to 
rely on intuition. Only accurate data, qualitative analysis can counteract this.

Thus, the main conclusion from the above is that the basis for health monitoring is correct population health data. Evidence of this lies in the recently published data that aim to examine how a healthy lifestyle is related to life expectancy that is free from major chronic diseases (Li et al., 2020). An investigation of more than 111000 people showed that the life expectancy free of diabetes, cardiovascular diseases, and cancer at the age of 50 was 23.7 years $(95 \%$ confidence, interval 22.6 to 24.7 ) for women who did not adopt low risk lifestyle factors, in contrast to 34.4 years (33.1 to 35.5 ) for women who adopted four or five low risk factors (diet, smoking, physical activity, alcohol consumption, and body mass index). At an age of 50, the life expectancy free of any of these chronic diseases was 23.5 (22.3 to 24.7) years among men who did not adopt low risk lifestyle factors and 31.1 (29.5 to 32.5) years in men who adopted four or five low risk lifestyle factors (diet, smoking, physical activity, alcohol consumption, and body mass index). For current male smokers who smoked heavily ( $\geq 15$ cigarettes/day) or obese men and women (body mass index $\geq 30$ ), their disease-free life expectancies accounted for the lowest proportion $(\leq 75 \%)$ of the total life expectancy at age 50 .

This paper is intended to give insight into some populationbased investigations on CVD and their risk factors in Latvia.

\section{HISTORICAL INSIGHT INTO POPULATION-BASED INVESTIGATIONS IN LATVIA}

Table 1 presents a list of selected investigations of cardiovascular risk factors in Latvia. The first investigation was the epidemiological study "Prevalence of Ischemic Heart Disease in Rīga Population" (Rīga, 1970) performed by Prof. E. Preimate, 1969-1970 (Preimate, 1972). The aim of this study was to detect the prevalence of coronary heart disease (CHD), cardiovascular disease risk factors and their

Table 1. Selected investigations of cardiovascular risk factors in Latvia

\begin{tabular}{|c|c|c|c|c|c|c|}
\hline Type of study & Title and CV risk factors analysed & Abbreviation & Years & $\begin{array}{l}\text { Sampling } \\
\text { size, } \mathrm{n}\end{array}$ & Age & Reference \\
\hline $\begin{array}{l}\text { Cross-sectional } \\
\text { epidemiological }\end{array}$ & $\begin{array}{l}\text { Prevalence of ischemic heart disease in the Rīga } \\
\text { population (Rose questionnaire, AH, Chol., BMI, } \\
\text { genetic predisposition, smoking) }\end{array}$ & Rīga 1970 & 1966-1970 & 2904 & $50-64$ & Preimate (1972) \\
\hline $\begin{array}{l}\text { Cross-sectional } \\
\text { epidemiological }\end{array}$ & $\begin{array}{l}\text { The most widespread chronic non-infectious diseases } \\
\text { in Latvia (Rose questionnaire, AH, BMI, glucose, } \\
\text { Chol.,Trigl., ECG, smoking, physical activity, } \\
\text { alcohol consumption) }\end{array}$ & Latvia 1993 & $1991-1993$ & 5449 & $\geq 25$ & $\begin{array}{l}\text { Bockans et al. } \\
\quad \text { (1994) }\end{array}$ \\
\hline $\begin{array}{l}\text { Cross-sectional } \\
\text { epidemiological }\end{array}$ & $\begin{array}{l}\text { Cardiovascular diseases and their risk factors in Rīga } \\
\text { population (Rose questionnaire, AH, BMI, glucose, } \\
\text { lipid profile, smoking, physical activity, alcohol } \\
\text { consumption) }\end{array}$ & Rīga 1997 & 1997 & 2646 & $20-69$ & Dzerve (2000) \\
\hline $\begin{array}{l}\text { Cross-sectional } \\
\text { epidemiological } \\
\text { (CINDI) }\end{array}$ & $\begin{array}{l}\text { Cardiovascular diseases and their risk factors in the } \\
\text { Kuldīga District (AH, BMI, glucose, lipid profile, } \\
\text { ECG, smoking, physical activity, alcohol } \\
\text { consumption) }\end{array}$ & Kuldīga 2000 & $1998-2000$ & 1826 & $25-64$ & Dzerve (2001) \\
\hline $\begin{array}{l}\text { Population } \\
\text { screening }\end{array}$ & $\begin{array}{l}\text { Population screening on diabetes (AH, BMI, } \\
\text { glucose, OGTT, smoking, genetic predisposition) }\end{array}$ & DIASCREEN & 2003 & 4625 & $>43$ & Pirags (2003) \\
\hline Follow-up study & $\begin{array}{l}\text { Management of hypertensives in Rīga population } \\
\text { (AH, BMI, glucose, lipid profile, smoking, physical } \\
\text { activity) }\end{array}$ & $\begin{array}{l}\text { AH management } \\
\text { Rīga }\end{array}$ & 2001-2009 & 729 & $40-69$ & Dzerve (2005) \\
\hline \multirow[t]{2}{*}{ Screening } & $\begin{array}{l}\text { Living conditions in Latvia (alcohol consumtion, } \\
\text { smoking) }\end{array}$ & NORBALT II & 1999 & $\begin{array}{l}3082 \\
\text { households }\end{array}$ & $\begin{array}{l}18 \text { years } \\
\text { and older }\end{array}$ & Aslund (2002) \\
\hline & $\begin{array}{l}\text { Health behaviour survey Questionnaire (smoking, } \\
\text { nutrition, physical activity, alcohol consumption, } \\
\text { blood pressure and blood cholesterol testing) }\end{array}$ & FINBALT & $\begin{array}{l}1998-2020 \\
\text { Each sec- } \\
\text { ond year }\end{array}$ & 3000 & $15-74$ & SPKC (2020) \\
\hline \multirow[t]{4}{*}{$\begin{array}{l}\text { Secondary } \\
\text { prevention study }\end{array}$} & $\begin{array}{l}\text { European survey of cardiovascular disease prevention } \\
\text { and diabetes (AH, BMI, glucose, lipid profile, } \\
\text { smoking, physical activity, alcohol consumption) }\end{array}$ & EUROASPIRE II & 2000-2001 & 403 & $<80$ & $\begin{array}{l}\text { EUROASPIRE II } \\
\text { Study Group (2001). } \\
\text { Latkovskis (2003) }\end{array}$ \\
\hline & & EUROASPIRE III & 2006-2007 & 519 & $<80$ & Kotseva (2010) \\
\hline & & EUROASPIRE IV & 2013-2014 & 463 & $<80$ & Kotseva (2016) \\
\hline & & EUROASPIRE V & 2017-2018 & 358 & $<80$ & Kotseva (2019) \\
\hline $\begin{array}{l}\text { Cross-sectional } \\
\text { epidemiological }\end{array}$ & $\begin{array}{l}\text { A population-based cross-sectional study of cardio- } \\
\text { vascular risk factors in Latvia (AH, BMI, glucose, } \\
\text { lipid profile, smoking, physical activity, alcohol con- } \\
\text { sumption, genetic predisposition) }\end{array}$ & Latvia 2009 & 2008-2009 & 4000 & $25-74$ & Erglis (2012) \\
\hline $\begin{array}{l}\text { Cross-sectional } \\
\text { epidemiological }\end{array}$ & $\begin{array}{l}\text { Cardiovascular and another non-communicable } \\
\text { disease risk factors in Latvian population (AH, BMI, } \\
\text { glucose, lipid profile, smoking, physical activity, } \\
\text { alcohol consumption, genetic predisposition) }\end{array}$ & Latvia 2020 & 2018-2020 & 4200 & $25-74$ & \\
\hline
\end{tabular}


correlations in the male population, age 50-64 years. The study was carried out in 2904 men, applying the WHO methods accessible in the 1970s.

The methods comprised the Rose questionnaire (Rose, 1962), the questionnaire for risk factor detection, blood pressure measurements, ECG registration, and measurements of total cholesterol level, proteins and glucose levels in urine. The degree of coronary artery occlusion was estimated by autopsy protocols in 107 cases.

The results showed that the prevalence of CHD was $23.9 \%$, which was correlated with age. The prevalence of six risk factors was observed: arterial hypertension $(\mathrm{AH})$, hypercholesterolemia (Hyper-Chol), increased body mass, smoking, congenital predisposition, and unsatisfactory sleep. $26.9 \%$ of the tested persons did not have any risk factor. $47.82 \%$ had one and $20.2 \%$ had two risk factors. The prevalence of $\mathrm{AH}(160 / 95 \mathrm{~mm} \mathrm{Hg})$ was $48.1 \%$. In the hypertensive group, CHD was observed 1.5 times more frequently than for normotensives. The prevalence of Hyper-Chol (Chol $\geq 5.7$ $\mathrm{mmol} / 1$ ) was $41.7 \%$ and CVD in this group was 1.3 times more frequent than in the group having a normal blood cholesterol level. $75 \%$ of the tested were smokers (Preimate, 1972).

The next significant epidemiological study was "The most widespread chronic non-infectious diseases in Latvia", Latvia, 1993), carried out between 1991 and 1993 (Bockans et al., 1994). The aim of this study was to determine the prevalence of chronic non-infectious diseases and their promoting factors, which influence the average life expectancy and life quality and require the greatest health care expenses. The object of the study was the adult population of both genders, over 25 years of age $(n=5449)$.

The study methods included the questionnaire and objective examination. Data on general health, some social and behavioural risk factors (physical activity, nutrition, smoking, alcohol intake and heredity) as well as cardiovascular and other system diseases were obtained using the questionnaire.

The objective examination included blood pressure measurement according to the WHO standard, body weight and height measurements, ECG registration by 12 standard leads, detection of total cholesterol, triglycerides and the glucose tolerance test (Tolonen et al., 2008). The study mainly was focused on the following CVD risk factors: blood pressure (BP), total cholesterol (T-Chol), elevated body mass index (BMI) and smoking. The weakness of the study was the low response rate: from a total number of 18040 expected persons, 5449 or $30.2 \%$ were questioned. Because the study was carried out in the politically and economically dramatic year of 1991 , the smallest response rate regarding questionnaires occurred at the final stage. The study ended in Riga, where the lowest response rate occurred. If the city of Riga would be excluded from the study, then the total response rate would increase to $42.6 \%$ (38.3\% for males and $46.9 \%$ for females). Therefore, the study results can only be partly attributed to Rìga and should be interpreted with great caution.

The unfavourable situation concerning the prevalence of CVD in the middle of the 1990s and the lack of systemic data about the Rìga population with its specific urban lifestyle were the reasons to conduct the study "Cardiovascular diseases and their risk factors in the Rīga population”, Rìga, 1997) performed at the Institute of Cardiology in 1997 (Dzerve et al., 2000). This study was supported by the Latvian Council of Science and the Rìga Sickness Insurance Fund.

The aim of the study was to assess the prevalence of CVD and their risk factors in the Rīga urban population as well as to evaluate health care costs and losses caused by CVD.

A randomised population group of the big city was formed from the Inhabitants Register. In total, 2646 persons (1117 men and 1527 women) were tested applying a method approved by the WHO standards adapted to local features (Tolonen, 2008). The method covered the standard Rose (Rose, 1962) questionnaire, anthropometrics measurements, measurements of blood pressure (BP), biochemical analysis (detection of blood lipid spectrum as well as blood glucose level) and ECG registration by 12 standard leads. The health risk factors (nutrition, alcohol intake, smoking, congenital predisposition, physical inactivity, concomitant diseases, life stress) and some socioeconomic factors were also studied.

The logical extension of the above mentioned study was the follow-up of hypertensive persons in the Riga population in the project "Management of Hypertensives in Rìga Population", which started in 2001 and continued in 2008. The aim of the study was to assess the effectiveness of arterial hypertension and risk factor control in the urban population for both genders, age group 40-65 years. The follow-up started with 729 participants and finished with 668 .

From 1998 to 2000, the epidemiological survey "Cardiovascular diseases and their risk factors in the Kuldiga District population" (Kuldīga 2000) was performed by the Latvian Institute of Cardiology in the framework of the WHO Countrywide Integrated Noncommunicable Disease Intervention Programme (CINDI) in the Kuldīga District, representing the countryside (844 men and 992 women) (Dzerve et al., 2001). The study methods included the questionnaire and objective examination. Data on general health, some social and behavioural risk factors (physical activity, nutrition, smoking, alcohol intake and heredity) were obtained using questionnaires. The objective examination included blood pressure measurement according to the WHO standard, body weight and height measurements, ECG registration by 12 standard leads, determination of total cholesterol and triglycerides and the glucose tolerance test. The risk factor screening in Kuldīga District showed a high prevalence of the main CVD factors, especially in the age group above 45 years, as well as the necessity of implementation of intervention programmes for their elimination. In this context 
the establishment of the Heart Health Office in Kuldiga, mass media campaigns, campaigns in schools (quit and win) and education of health professionals in primary prevention were the first steps of intervention.

In the framework of "The Population Screening Programme on Diabetes - DIA-Screen", 4625 persons of both genders, aged above 45 years, were observed by practical physicians in 16 different regions and towns in Latvia (Pirags et al., 2003). According to the study protocol of the DIA-Screen programme, males and females aged over 45 were enrolled into the study. The risk group for diabetes enrolled individuals aged 45 years, who were overweight $(+5$ risk points), had arterial hypertension ( +5 points), a parent, sibling or child with diabetes ( +2 popints), or were smokers (+1 point). Patients aged 45-65 years were estimated with 9 points. The study physician had to calculate the severity of risk for diabetes according to an internationally accepted questionnaire derived from a diabetes screening questionnaire recommended by the American Association of Diabetes (Herman, 1995), only adding smoking ( +1 risk point), but excluding sedentary life style ( +5 risk points) to avoid potential confounding results. In total, the family physicians involved in DIA-Screen programme had 193000 registered patients (8.2\% of the population of Latvia). Data of registered patients presented by study physicians included $53 \%$ individuals (102 000). Additionally, data on BMI and arterial hypertension control were obtained.

In addition, there were some surveys mainly centred on other specific problems, but which estimated CVD risk factors. These were surveys of living conditions in Latvia, performed twice by the Latvia Statistical Bureau in cooperation with the Norwegian Institute for Applied Social Science, in 1994 and 1999 (Aslund and Tyldum, 2002). The studies took place as part of the NORBALT I and NORBALT II Project. The studies were based on a broad spectrum of issues and the questionnaire was administered to more than 3000 households. The respondents were selected at random throughout Latvia, and the selection could be considered as representative. Living conditions surveys provided insight into the relation among health self-evaluation, some CVD risk factors (alcohol consumption, smoking), health-related activities and various socioeconomic factors: income, expenses, education, demographic and other factors that influence living conditions. Health Behaviour surveys among the Latvian Adult Population were conducted every two years since 1998 as the "FINBALT study", in collaboration with Lithuania, Estonia, and Finland during 1998-2010 and "Health Behaviour Study" from 2012 (Anonymous, 2020c). The aim of health behaviour surveys was to collect information about individuals' health behaviour, to evaluate actual and potential public health problems associated with health behaviour, to investigate demographic and geographic distribution, and to gain accurate evidence-based information for future health promotion and health education programmes. Information on health-related behaviour like smoking, alcohol consumption, nutrition, physical activity, oral hygiene, and traffic safety among the Latvian adult population aged 15-74 is given in publications of the Latvian Centre for Disease Prevention and Control (Anonymous, 2020b). Also, data on self-assessed health status and usage of health services (frequency of doctor and dentist visits, trends in vaccination, assessment of blood pressure and cholesterol levels) are provided. Until 2010, the FINBALT Health Monitoring Survey used a mailed questionnaire to a randomly selected, representative sample of the population, but from 2011, study samples using the combined sampling method — stratified random sampling and quota method - were selected from the general population. The total sample sizes were between 3000 and 3600 people. The samples were stratified by sex, age, place of residence, city, municipality region and nationality. From 2011, data were collected by face-to-face standardised interviews. The survey instrument contains 110-130 questions including cardiovascular risk related items: smoking, arterial blood pressure, nutrition, physical activity, and alcohol use.

Considering the high prevalence of cardiovascular diseases in Latvia, especially coronary heart disease, it is important to understand the prevalence and management of risk factors not only in the general population, but also in the coronary patient population.

For this purpose, Latvia participated in four surveys with the acronym EUROASPIRE: European Action on Secondary and Primary Prevention through Intervention to Reduce Events (Anonymous, 2001; Latkovskis et al., 2003; Kotseva et al., 2010; 2016; 2019) from 2001. The aim of EUROASPIRE surveys was to describe the lifestyle and risk factor management in coronary patients and people at high risk of developing CVD, and to see whether the practice of preventive cardiology had improved in comparison with the previous surveys. The geographical area of Riga and the Rìga District, and two hospitals were selected. The data collection lasted at least six months after the date of urgent hospital admission and was carried out in two steps. The following information was obtained: personal and demographic details, cardiac history, history of the risk factors (hypertension, diabetes, lipids, and smoking). The following measurements were carried out: height, weight, blood pressure, blood lipids (total cholesterol, high-density lipoprotein cholesterol (HDL), triglycerides (Tg) and lowdensity lipoprotein cholesterol (LDL)), glucose (Gl) and amount of breath carbon monoxide. Descriptive statistics were used to report the prevalence of risk factors, their recording and management.

It was found that the prevalence of risk factors in CHD patients of Latvia was much higher than in the population studies: raised blood pressure in EA III patients was $58.6 \%$ (44.8\% in Latvia, 2009), overweight $80.9 \%$ (37.7\% in Latvia, 2009), elevated total cholesterol $81.9 \%$ (75.4\% in Latvia, 2009), elevated TG 38.9\% (27.0\% in Latvia, 2009), and decreased HDL 25.5\% (16.3\% in Latvia, 2009) (Kotseva et al., 2010; Erglis et al., 2012). 
An important stage in the development of the epidemiology of cardiovascular diseases in Latvia was the cross-sectional population survey on cardiovascular risk factors in 20082009 (Erglis et al., 2012). The survey was performed according to internationally established standards and protocols. The target population was all adults aged 25-74 years living in Latvia. The total number of the selected persons in this study was 6000 . They were divided in ten sub-groups with five-year age intervals. There were 600 persons (300 men and 300 woman) in each subgroup. This was the first population based study with a high enough response rate $(63.5 \%)$.

The survey established the high prevalence of the classical risk factors.

\section{"PORTRAITS" OF THE LATVIAN POPULATION RE- GARDING CVD RISK FACTORS}

Thus, the four most representative epidemiological studies in Latvia on the prevalence of cardiovascular risk factors on a regional and entire country level are: Latvia 1993, Rīga 1997, Kuldīga District 2000 and Latvia 2009. Rīga 1997 represents the population of a big city, Kuldiga 2000 represents the countryside population and Latvia 1993 and Latvia 2009 characterise the mixed population. The results can be referred to as the "moment portrait" of the populations at a definite time. All the data selected for this demonstration were obtained using the same methods, with equal criteria for risk factor detection. The results were age-standardised using the European Standard Population.

The prevalence of the most significant risk factors: $\mathrm{AH}$, BMI, Hyper-Chol, Hyper-Tg, smoking, abusive alcohol consumption, and physical inactivity at leisure time are shown in Table 2. In this Table, equal-age (25-74 years) populations were selected from the above-mentioned population samples.

The results of all of the mentioned studies confirmed high prevalence of $\mathrm{AH}$ in Latvia. The seriousness of the problem observed in the 1990s of the last century and the first decade of the $21^{\text {st }}$ century was already reported in our publications (Preimate, 1972; Bockans et al., 1994; Dzerve, 2000; 2001). In this context, the epidemiological data from the cross-sectional population-based study of 2018-2020 will

Table 2. Prevalence (\%) of CVD risk factors in Latvia, Rīga and Kuldīga populations (age 25-74) (age-standardised using the European Standard Population)

\begin{tabular}{|c|c|c|c|c|}
\hline $\mathrm{BP} \geq 140 / 90 \mathrm{mmHg}$ & $\begin{array}{c}\text { Latvia } 1993 \\
\%\end{array}$ & $\begin{array}{c}\text { Rìga } 1997 \\
\%\end{array}$ & $\begin{array}{c}\text { Kuldīga } 2000 \\
\%\end{array}$ & $\begin{array}{l}\text { Latvia } 2009 \\
\%,(95 \% \mathrm{CI})\end{array}$ \\
\hline Men & $43.5 \pm 1.86$ & $45.6 \pm 2.33$ & $41.4 \pm 2.35$ & $52.9(50.3-55.5)$ \\
\hline Women & $36.2 * \pm 1.45$ & $37.7 * \pm 1.63$ & $34.3 * \pm 1.97$ & $40.2 *(38.3-42.2)$ \\
\hline Total & $39.3 \pm 1.15$ & $38.4 \pm 1.35$ & $37.6 \pm 1.52$ & $44.8(43.2-36.4)$ \\
\hline$\underline{\mathrm{BMI}} \geq 25 \mathrm{~kg} / \mathrm{m}^{2}$ & $\%$ & $\%$ & $\%$ & $\%(95 \% \mathrm{CI})$ \\
\hline Men & $56.4 \pm 2.15$ & $53.0 \pm 2.55$ & $49.6 \pm 2.59$ & $70.2(64.2-75.3)$ \\
\hline Total & $61.7 \pm 1.46$ & $53.5 \pm 1.64$ & $51.6 \pm 1.79$ & $67.8(64.0-72.3)$ \\
\hline$\underline{\text { Total Chol. } \geq 5.18 \mathrm{mmol} / \mathrm{L}}$ & $\%$ & $\%$ & $\%$ & $\mathrm{TC}>5.0 \mathrm{mmol} / \mathrm{L} \%(95 \% \mathrm{CI})$ \\
\hline Men & $52.9 \pm 2.03$ & $64.6 \pm 2.51$ & $65.1 \pm 2.89$ & $72,0(69.6-74.4)$ \\
\hline Women & $55.4 \pm 1.77$ & $61.3 \pm 2.32$ & $61.3 \pm 2.62$ & $78.0 *(76.4-79.7)$ \\
\hline Total & $54.2 \pm 1.3$ & $62.0 \pm 1.79$ & $63.2 \pm 1.94$ & $75.2(73.8-76.6)$ \\
\hline$\underline{\text { Triglycerides } \geq 1.7 \mathrm{mmoL}}$ & $\%$ & $\%$ & $\%$ & $\%(95 \% \mathrm{CI})$ \\
\hline Men & $17.8 \pm 1.19$ & $25.9 \pm 1.52$ & $27.9 \pm 1.90$ & $33.9(31.4-36.4)$ \\
\hline Women & $15.1 \pm 0.93$ & $18.2^{*} \pm 1.21$ & $15.5^{*} \pm 1.31$ & $24.1 *(22.4-25.8)$ \\
\hline Total & $16.3 \pm 0.73$ & $21.2 \pm 1.03$ & $21.3 \pm 1.13$ & $27.0(25.6-28.4)$ \\
\hline Glucose $\geq 5.8 \mathrm{mmol} / \mathrm{L}$ & $\%$ & $\%$ & $\%$ & $\mathrm{Gl}>5.6 \mathrm{mmol} / 1 \%(95 \% \mathrm{CI})$ \\
\hline Men & & $16.2 \pm 1.38$ & $16.5 \pm 1.45$ & $41.6(37.1-43.5)$ \\
\hline Women & - & $13.3^{*} \pm 1.15$ & $15.6 \pm 1.32$ & $29.8 *(27.2-32.2)$ \\
\hline Total & & $13.7 \pm 0.89$ & $16.0 \pm 0.98$ & $34.1(32.2-35.8)$ \\
\hline Daily smokers + ex-smokers & $\%$ & $\%$ & $\%$ & $\%(95 \% \mathrm{CI})$ \\
\hline Men & $68.9 \pm 2.12$ & $72.4 \pm 3.05$ & $60.8 \pm 2.87$ & $56.4(46.3-61.0)$ \\
\hline Women & $14.2 * \pm 0.84$ & $28.9^{*} \pm 1.68$ & $21.7 * \pm 1.61$ & $20.5^{*}(18.1-22.9)$ \\
\hline Total & $37.7 \pm 1.03$ & $47.3 \pm 1.61$ & $39.8 \pm 1.58$ & $33.3(30.6-35.6)$ \\
\hline Alcohol intake $\geq 2-3$ times a month & $\%$ & $\%$ & $\%$ & $\%(95 \% \mathrm{CI})$ \\
\hline Men & $41.3 \pm 1.77$ & $60.2 \pm 2.81$ & $32.0 \pm 2.0620 .3 * \pm 1.56$ & $33.4(30.1-38,6)$ \\
\hline Women & $11.2 * \pm 0.92$ & $31.8^{*} \pm 1.76$ & $25.7 \pm 1.27$ & $13.5^{*}(11.2-15.8)$ \\
\hline Total & $26.5 \pm 0.99$ & $43.8 \pm 1.56$ & & $23.1(21.0-25.1)$ \\
\hline Women & $54.9 \pm 1.62$ & $54.4 \pm 2.24$ & $50.1 * \pm 1.91$ & $80.3(77.1-84.2)$ \\
\hline Total & $53.9 \pm 1.22$ & $53.7 \pm 1.70$ & $26.8 \pm 1.29$ & $78.8(77.0-81.7)$ \\
\hline
\end{tabular}

$* p<0.05$ comparing men and women; ** proportion of respondents who do not engage in 30 minutes long physical exercises at least 4-6 times a week by demographic groups 
be extremely important to judge the trends in the prevalence of this unfavourable RF over the last 30 years. It is necessary to emphasise that the prevalence rate of $\mathrm{AH}$ between 40-45\% ranks Latvia among the countries with a high prevalence of hypertension. The data for several Eastern European countries are similar, while in West European countries and North America the prevalence of AH was between 22 to 30\% (Wolf-Maier et al., 2003; Anonymous, 2017) which indicates the potential to decrease the $\mathrm{AH}$ prevalence rate in Latvia.

The prevalence of the other risk factors varied in different studies. The rate of being overweight, which was high in all of the surveys, was 7-16\% higher in Latvia 2009 in comparison to the other studies. There was also a comparatively higher prevalence of elevated T-Chol, Tg and Gl levels in the Latvia 2009 survey in comparison to the other studies. In the urban population of Rìga 1997, the prevalence of abusive alcohol consumption and smoking was significantly higher than in the Kuldiga 2000 countryside population and in the Latvia 1993 and 2009 mixed populations (Preimate, 1972; Bockans et al., 1994; Dzerve, 2000; 2001; Pirags et al., 2003; Erglis et al., 2012).

Attention should be paid to the high number of the risk factors per individual in all of the studies. The populationbased epidemiological study of 2009 had a mean number of cardiovascular RF of $2.99 \pm 0.026$ for the total study population. The male group had a significantly greater mean number of RF than the female group $(3.45 \pm 0.04$ vs $2.72 \pm$ 0.03) (Erglis et al., 2012). Figure 1 shows that the number of the RF increases with age both in men and women. A positive correlation between age (25-74 years) and the number of the RF was found.

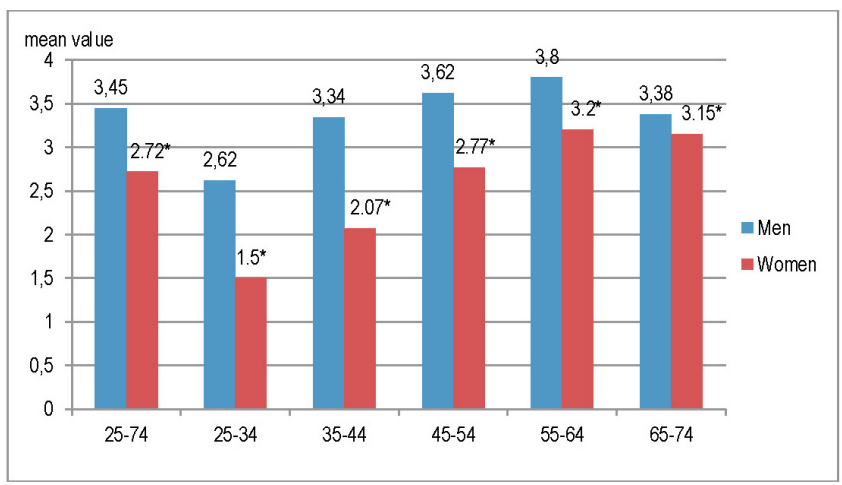

Fig. 1. The mean number of risk factors (elevated blood pressure, Body Mass Index, lipid and glucose level, smoking) per individual by different age groups. Data from epidemiological study of 2009) $(* p<0.05$ comparing men and women)

The prevalence of smoking (Table 3) and elevated blood pressure (Table 4) could serve as examples of RF variation in different studies in a small country

Thus, data in the tables above show four different "portraits" of the prevalence of CVD risk factors in the period of almost 20 years. There are several reasons for the differences in the results of the different studies. One of these is the regional difference between city and countryside. Other reasons are differences in diet (fatty milk, fatty meat and farinaceous foods) and working outdoors.

We should not ignore the political and economic transition period, which led to more stressful situations for the population. In this context, the data on health self-estimation in the above-mentioned study populations are very impressive.

Table 3. Prevalence of daily smokers $(\%, \mathrm{CI})$ in men and women by different age groups

\begin{tabular}{|c|c|c|c|c|c|c|c|c|}
\hline \multirow{2}{*}{$\begin{array}{c}\text { Age groups, } \\
\text { years }\end{array}$} & \multicolumn{2}{|c|}{$25-34$} & \multicolumn{2}{|c|}{$35-44$} & \multicolumn{2}{|c|}{$45-54$} & \multicolumn{2}{|c|}{$55-64$} \\
\hline & men & women & men & women & men & women & men & women \\
\hline Latvia 1993 & $\begin{array}{c}74.9 \\
68.7-81.0\end{array}$ & $\begin{array}{c}22.2 \\
16.8-27.5\end{array}$ & $\begin{array}{c}67.0 \\
59.2-72.4\end{array}$ & $\begin{array}{c}25.0 \\
19.5-30.5\end{array}$ & $\begin{array}{c}61.2 \\
54.6-67.8\end{array}$ & $\begin{array}{c}24.7 \\
19.2-30.2\end{array}$ & $\begin{array}{c}38.6 \\
32.2-45.1\end{array}$ & $\begin{array}{c}10.9 \\
6.7-15.1\end{array}$ \\
\hline Rīga 1997 & $\begin{array}{c}57.5 \\
50.2-62.8\end{array}$ & $\begin{array}{c}28.3 \\
21.1-35.0\end{array}$ & $\begin{array}{c}52.6 \\
44.6-55.3\end{array}$ & $\begin{array}{c}26.1 \\
19.8-32.8\end{array}$ & $\begin{array}{c}39.1 \\
28.9-47.8\end{array}$ & $\begin{array}{c}8.2 \\
5.4-11.0\end{array}$ & $\begin{array}{c}29.8 \\
20.1-36.9\end{array}$ & $\begin{array}{c}5.8 \\
4.2-7.5\end{array}$ \\
\hline Kuldiga 2000 & $\begin{array}{c}60.3 \\
57.4-63.1\end{array}$ & $\begin{array}{c}30.1 \\
27.8-33.0\end{array}$ & $\begin{array}{c}55.4 \\
52.8-58.0\end{array}$ & $\begin{array}{c}27.5 \\
24.7-29.4\end{array}$ & $\begin{array}{c}39.9 \\
35.8-42.9\end{array}$ & $\begin{array}{c}12.8 \\
10.3-14.0\end{array}$ & $\begin{array}{c}32.4 \\
30.1-34.3\end{array}$ & $\begin{array}{c}6.6 \\
5.7-7.8\end{array}$ \\
\hline Latvia 2009 & $\begin{array}{c}46.3 \\
40.7-50.4\end{array}$ & $\begin{array}{c}22.3 \\
20.1-24.7\end{array}$ & $\begin{array}{c}41.8 \\
39.4-44.0\end{array}$ & $\begin{array}{c}13.7 \\
11.4-15.4\end{array}$ & $\begin{array}{c}38.8 \\
37.0-40.8\end{array}$ & $\begin{array}{c}15.4 \\
13.7-16.8\end{array}$ & $\begin{array}{c}29.1 \\
27.0-31.0\end{array}$ & $\begin{array}{c}9.5 \\
8.0-10.7\end{array}$ \\
\hline
\end{tabular}

Table 4. Prevalence of elevated blood pressure (BP 140/90) (\%; 95\%CI) in men and women by different age groups

\begin{tabular}{|c|c|c|c|c|c|c|c|c|}
\hline \multirow{2}{*}{$\begin{array}{l}\text { Age groups, } \\
\text { years }\end{array}$} & \multicolumn{2}{|c|}{$25-34$} & \multicolumn{2}{|c|}{$35-44$} & \multicolumn{2}{|c|}{$45-54$} & \multicolumn{2}{|c|}{$55-64$} \\
\hline & men & women & men & women & men & women & men & women \\
\hline Latvia 1993 & $\begin{array}{c}23.7 \\
17.3-30.1\end{array}$ & $\begin{array}{c}22.9 \\
17.9-28.0\end{array}$ & $\begin{array}{c}27.5 \\
20.8-34.2\end{array}$ & $\begin{array}{c}35.1 \\
29.4-40.8\end{array}$ & $\begin{array}{c}33.2 \\
26.5-39.9\end{array}$ & $\begin{array}{c}47.1 \\
41.3-53.0\end{array}$ & $\begin{array}{c}38.7 \\
32.1-45.2\end{array}$ & $\begin{array}{c}60.8 \\
54.9-66.6\end{array}$ \\
\hline Rīga 1997 & $\begin{array}{c}17.1 \\
12.7-22.3\end{array}$ & $\begin{array}{c}7.2 \\
5.3-9.8\end{array}$ & $\begin{array}{c}35.8 \\
30.2-39.5\end{array}$ & $\begin{array}{c}25.5 \\
20.2-30.4\end{array}$ & $\begin{array}{c}55.3 \\
51.1-60.0\end{array}$ & $\begin{array}{c}44.8 \\
39.3-50.1\end{array}$ & $\begin{array}{c}63.8 \\
59.4-69.2\end{array}$ & $\begin{array}{c}68.3 \\
61.4-73.7\end{array}$ \\
\hline Kuldiga 2000 & $\begin{array}{c}31.0 \\
29.2-33.3\end{array}$ & $\begin{array}{c}5.2 \\
4.4-6.0\end{array}$ & $\begin{array}{c}39.2 \\
36.8-42.4\end{array}$ & $\begin{array}{c}19.4 \\
17.0-22.1\end{array}$ & $\begin{array}{c}51.3 \\
48.8-54.0\end{array}$ & $\begin{array}{c}46.7 \\
43.1-50.0\end{array}$ & $\begin{array}{c}66.0 \\
62.4-70.8\end{array}$ & $\begin{array}{c}73.1 \\
69.3-76.9\end{array}$ \\
\hline Latvia 2009 & $\begin{array}{c}23.7 \\
20.0-25.3\end{array}$ & $\begin{array}{c}8.2 \\
7.4-9.2\end{array}$ & $\begin{array}{c}39.9 \\
37.3-41.1\end{array}$ & $\begin{array}{c}17.1 \\
16.0-18.2\end{array}$ & $\begin{array}{c}50.2 \\
48.9-52.0\end{array}$ & $\begin{array}{c}33.0 \\
31.5-34.9\end{array}$ & $\begin{array}{c}60.3 \\
58.8-61.9\end{array}$ & $\begin{array}{c}54.0 \\
52.1-55.9\end{array}$ \\
\hline
\end{tabular}


The Riga population with greater alcohol abuse and high smoking rate are related to the high rates of "bad" values. The self-evaluation of health status according to the Likerttype scale (good, satisfactory, bad health) showed large differences in the studies analysed. In the Rìga 1997 population, $15.67 \%$ of responders estimate their health status as bad, compared to $11.8 \%$ in Kuldīga 2000 , $9.6 \%$ in Latvia 1993 and $6.5 \%$ in the Latvia 2009 survey. Moreover, the health status in the Riga 1997 population was estimated as "good" only by $19.9 \%$ of the respondents, compared to $24.4 \%$ in Latvia 1993, 30.4\% in Kuldīga 2000 and 42.6\% in Latvia 2009. The differences in various age, gender and social groups were significant. Self-estimation of the health status gradually worsened with age. Men rated their health more positively than women, which partly can be explained by the higher average age in women or less serious attitude towards their health in men. Large female-male differences in self-reported health and functioning are mentioned in other studies (Zajacova et al., 2017, Boerma et al., 2016). Women report worse self-rated health than men on average but this only holds through mid-adulthood and is reversed at older ages (Zajacova et al., 2017). The 59 country study suggested that a mix of biological factors and societal gender inequalities were major contributing factors to gender gaps in self-reported measures of health (Boerma et al., 2016). However, we would like to emphasise that only follow-up studies in the same population can indicate the true reasons causing the data variabilities.

\section{WHY DO WE NEED POPULATION-BASED INVESTI- GATIONS OF THE CVD RISK FACTORS?}

In conclusion, we would like to briefly answer the abovementioned question that we have raised.

Returning to the review of studies mentioned in Table 1, it can be seen that, with the exception of the studies in 1993 and of 2009, the epidemiological studies covered only populations of certain districts (Rīga, Kuldīga) or nosologically limited population groups (diabetes, arterial hypertension) and GP patients on their own initiative. Until now, Latvia has not been able to implement the internationally accepted practice of conducting regular country-wide surveys. National health interview surveys (HIS) are regularly carried out in 14 of the 18EU/EFTA Member States, but national population-based Health Examination Surveys (HES) with a comprehensive focus have been conducted at regular or irregular intervals in five countries (Finland, Germany, Ireland, the Netherlands, and UK) and in a large region in Spain (Koponen and Aromaa, 2003; Kuulasmaa et al., 2012). HISs deliver valuable information on health and health-related topics and interviews and questionnaires are the only way to obtain data on, e.g. symptoms and health related behaviour. However, clinical measurement is needed to obtain valid information on many chronic conditions, functional limitations and disabilities, and on several key health determinants. Such data are not available from regular statistical sources and the information can only be obtained by carrying out HES or by supplementing the HIS by
HES methods (Koponen and Aromaa, 2001). In addition to these, European HES has an important role in sharing experiences between countries, which is particularly important for countries with little earlier experience on national HESs and for countries adding new measurement to their HESs (Kuulasmaa and Tolonen, 2013). This is reinforced by the fact that the last population-based survey of the prevalence of the cardiovascular risk factors in Latvia took place in 2008-2009.

Thus, the data from the mentioned studies no longer really correspond to the real changes in both health policy and the rapid development of certain sectors (e.g., invasive cardiology). All the preconditions for creating a new epidemiological database for the population of Latvia have been developed at least since 2015 in order to be able to formulate both the primary and secondary prevention tasks in the country more precisely.

Therefore, population-based prevention through changes in lifestyle and environment is indeed the most cost-effective and sustainable way of controlling cardiovascular and other major non-communicable diseases. Epidemiological studies are acknowledged as the most informative in the field of risk factor (RF) investigations. Evidence from crosssectional and longitudinal studies shows not only the prevalence of RF and their intercorrelation and relationship to cardiovascular diseases (CVD), but also the changes of these data in different periods for the investigated population. These relationships observed in a random sample can be referred to the population in general. In an early monograph on CVD diagnostic methods the world-renowned epidemiologists G. A. Rose and H. Blackburn had already considered that epidemiological research can only indicate the reasons for chronic diseases (Rose et al., 1982). The relationships, of course, must be proved by clinical and experimental observations, and scientifically valid preventive programmes must be developed.

The Tecumseh Community Health Study (Epstein,1967), Framingham Study (Dawber et al., 1957), The North Karelia Project (Puska, 1995; Puska et al., 2016), and CINDI (Anonymous, 1992) are the most representative classic epidemiological studies. The North Karelia Project is an excellent example of the importance of epidemiological studies. The repeated analysis of population risk factors with following intervention of the more significant risk factors helped to decrease the total death rate in the Karelia region in $1990-1992$ by $39.5 \%$ compared to $1969-1971$. Coronary mortality was reduced by $84 \%$ in the middle age population from 1972 to 2014 (Vartiainen, 2018).

Therefore, based on the experience of previous epidemiological studies and the demographic situation in Latvia, it is nationally important to conduct a "cross-sectional" or onemoment epidemiological study of the entire Latvian population, which should be performed in the shortest possible time (4-6 months). 
Data from cross-sectional studies serve to assess the current heart health situation of the population. These data serve as a basis for taking appropriate immediate and follow-up preventive measures. Based on the prevalence data of a particular RF or a group of RFs in a population, it is possible to model their dynamics and their impact on the morbidity and mortality over a period of time as part of specific preventive measures. In turn, long-term (longitudinal) studies of the same population are vital for the control and correction of the modelled situations.

\section{REFERENCES}

Anonymous (1992). Handbook for Process Evaluation in Noncommunicable Disease Prevention. WHO/CINDI, Copenhagen. Available at: https://apps.who.int/iris/bitstream/handle/10665/108196/E66338.pdf?sequence=1\&isAllowed=y (accessed 20 May 2020).

Anonymous (2001). Lifestyle and risk factor management and use of drug therapies in coronary patients' from 15 countries: principal results from EUROASOIRE II. EUROASPIRE II Study Group. Eur. Heart J., 22, 554-572.

Anonymous (2017). NCD Risk Factor Collaboration. Worldwide trends in blood pressure from 1975 to 2015: a pooled analysis of 1479 population-based measurement studies with 19.1 million participants. Lancet, 389, 37-55

Anonymous (2019). Aptauja: 73\% iedzīvotāju uzskata, ka prioritāri vairāk finansējuma jānovirza veselības aprūpei [Poll: 73\% of the population consider that more funding should be directed to health care]. Available at: https://medicine.lv/raksti/aptauja-73-iedzivotaju-uzskata-ka-prioritarivairak-finansejuma-janovirza-veselibas-aprupei (accessed 12 October 2020).

Anonymous (2020a). Noncommunicable diseases and mental health. NCD Global Monitoring Framework. Available at:

https://www.who.int/nmh/global_monitoring_framework/en/ (accessed 12 October 2020).

Anonymous (2020b). Pētījumi un ziņojumi [Studies and reports]. Available at https://spkc.gov.lv/lv/statistika-un-petijumi/ (accessed 12 October 2020).

Anonymous (2020c). Veselību ietekmējošo paradumu pētijjumi [Studies of health-related behavior]. Available at:

https://www.spkc.gov.lv/lv/veselibu-ietekmejoso-paradumu-petijumi (accessed 12 October 2020).

Aslund, A.Tyldum, G. (2002) The NORBALT project. In: Hagerty, M. R., Vogel, J., Moller, V. (eds.) Assessing Quality of Life and Living Conditions to Guide National Policy (e-book). Kluwer Academic publications, 177-189. Available at:

https://www.google.lv/search?tbm=bks\&hl=lv\&q=norbalt+I (accessed 12 May 2020)

Bockans, I., Brigis, G., Dzerve, V., Marga, M., Neimanis, V., Raslavs, R., Robule, V., Stepanovs, I., Zabarovskis, J. (1994). The Most Widespread Chronic Non-infectious Diseases in Latvia. Epidemiologic study. Riga, 80 pp.

Boerma T., Hosseinpoor, A. R., Verdes, E. Chatterji S. (2016) A global assessment of the gender gap in self-reported health with survey data from 59 countries. BMC Public Health 16, 675.

Dawber, T. R., Moore, F. E., Mann, G. V. (1957). Coronary heart disease in the Framingham Study. Amer. J. Public Health, 47, 4-24.

Dzerve, V. (ed.) (2000). Assessment of Cardiovascular Diseases and their Risk Factors in the Riga Population (prevalence, interaction, health care costs). Latvian Institute of Cardiology, Rīga. 48 pp.

Dzerve, V. (ed.) (2001). Assessment of Cardiovascular Diseases and their Risk Factors in the Population of Kuldiga Region. Finnish-Latvian Pilot Project on Prevention of Cardiovascular Diseases. CINDI LATVIA. Rīga, $61 \mathrm{pp}$.
Dzerve, V., Lejnieks, A. (2005). Hypertension in Latvia: Epidemiology and management. Blood Pressure, Suppl. 2, 29-32.

Epstein, F. H. (1967). Some uses of prospective observations in the Tecumseh Community Health Study. Proc. Roy. Soc. Med., 60, 56-60.

Erglis, A., Dzerve, V., Pahomova-Strautina, J., Narbute, I., Jegere, S., Mintale, I., Ligere, R., Apinis, P., Lejnieks, A., Misina, D., Rozenbergs, A. (2012). A population-based cross-sectional study of cardiovascular risk factors in Latvia. Medicina (Kaunas), 48 (6), 310-316.

Herman, W. H., Smith, P. J., Thomson, T. J., Engelgau, M. M., Aubert, M. E. (1995). A new and simple questionnaire to identify people at increased risk for undiagnosed diabetes. Diabetes Care, 18 (3), 382-387.

Koponen. P., Aromaa, A. (2003). Health Examination Surveys (HES). Review of literature and inventory of surveys in the EU/EFTA Member States. Available at: https://ec.europa.eu/health/ph_projects/1998/monitoring/fp_monitoring_1998_annexe4_02_en.pdf (accessed 15 August 2020).

Kotseva, K., Wood, D., De Backer, G., De Bacquer, D., Pyörälä, K., Reiner, Z., Keil, U. (2010). EUROASPIRE Study Group. EUROASPIRE III. Management of cardiovascular risk factors in asymptomatic high-risk patients in general practice: cross-sectional survey in 12 European countries. Eur. J. Cardiovasc. Prev. Rehabil., 17 (5), 530-540.

Kotseva, K., Wood, D., De Bacquer, D., Rydén, L., Jennings, C., Gyberg, V., Amouyel, P., Bruthans, J., Conde, A.C., Cífková, R. et al. (2016). EUROASPIRE IV: A European Society of Cardiology survey on the lifestyle, risk factor and therapeutic management of coronary patients from 24 European countries. Eur. J. Prev. Cardiol., 23 (6), 636-648.

Kotseva, K., De Backer, G., De Bacquer, D., Rydén, L., Hoes, A., Grobbee, D., Maggioni, A., Marques-Vidal, P., Jennings,C., Abreu, A. et al. (2019). Lifestyle and impact on cardiovascular risk factor control in coronary patients across 27 countries: Results from the European Society of Cardiology ESC-EORP EUROASPIRE V registry. Eur. J. Prev. Cardiol., 26 (8), 824-835.

Kuulasmaa, K., Tolonen H., Koponen P., Kilpeläinen K., Avdicovị M., Broda G., Calleja N., Dias C., Gösswald A., Kubinova R. et al. (2012). An overview of the European Health Examination Survey Pilot Joint Action. Arch. Public Health, 70 (1), 20.

Kuulasmaa, K., Tolonen, H. (2013). What is EHES and why is it needed? National Institute for Health and Welfare, 2013. Discussion_Paper 2013 007. Avilable at: https://www.julkari.fi/bitstream/handle/10024/104395/URN_ISBN_978-952-245-844-5.pdf?sequence $=1 \&$ isAllowed=y (accessed 15 August 2020).

Latkovskis, G., Kalnins, U., Sika, G. (2003). Evaluation of secondary prevention measures in patients with coronary heart disease in Latvia. Seminars Cardiol., 9 (1), 28-37.

Li, Y., Schoufour, J., Wang, D. D., Pan, A., Liu, X., Song, M., Liu, G., Shin, H. J., Sun, Q. et al. (2020). Healthy lifestyle and life expectancy free of cancer, cardiovascular disease, and type 2 diabetes: Prospective cohort study. Brit. Med. J., 368, 16669.

Pirags, V., Bricina, N., Eisaka, I. (2003). Reālā saslimstība ar 2. tipa cukura diabētu Latvijā [Real morbidity with type 2 diabetes mellitus in Latvia]. Latvijas Ārsts, No. 12, 29-33 (in Latvian).

Preimate, E. (1972). Incidence of ischemic heart disease and various risk factors among the male population of Riga. Kardiologiia, 12 (8), 48-53 (in Russian).

Rose, G. A. (1962). The diagnosis of ischaemic heart pain and intermittent claudication in field surveys. Bull. World Health Organ., 27, 645-658.

Puska, P. (1995). The North Karelia Project 20 years Results and Experiences. Helsinki. 363 pp.

Puska, P., Vartiainen, E., Nissinen, A., Laatikainen, T., Jousilahti, P. (2016). Background, principles, implementation, and general experiences of the North Karelia Project. Glob. Heart., 11 (2), 173-178.

Rose, G. A., Blacbum, H., Gillium, R. F., Prineas, R. J. (1982). Cardiovascular Survey Methods. Vol. 56. 2nd edition. WHO, Geneva. 178 pp. 
Roth, G. A., Abate, D., Abate, K. H., Abay, S. M., Abbafati, C., Abbasi, N., Abbastabar, H., Abd-Allah, F., Abdela, J., Abdelalim, A. (2018). Global, regional, and national age-sex-specific mortality for 282 causes of death in 195 countries and territories, 1980-2017: A systematic analysis for the Global Burden of Disease Study 2017. Lancet, 392 (10159), 1736-1788.

Tolonen, H., Koponen, P., Aromaa, A., Conti, S., Graff-Iversen, S., Grøtvedt, L., Kanieff, M., Mindell, J., Natunen, S., Primatesta, P., Verschuren, M., Viet, L., Kuulasmaa, K. (2008). Review of health examination surveys in Europe. Available from:

http://www.julkari.fi/bitstream/handle/10024/103057/2008b18.pdf (accessed 15 August 2020).

Received 4 June 2020

Accepted in the final form 30 September 2020
Vartiainen, E. (2018). The North Karelia Project: Cardiovascular disease prevention in Finland. Glob. Cardiol. Sci. Pract., 2018 (2), 13.

Zajacova, A., Huzurbazar S., Todd M. (2017). Gender and the structure of self-rated health across the adult life Span. Soc. Sci. Med., 187, 58-66.

Wolf-Maier, K., Cooper, R. S., Banegas, J. R. Giampoli, S., Hense, H.-W., Joffres, M., Kastarinen, M., Poulter, N., Primatesta, P., RodríguezArtalejo, F., Stegmayr, B., Thamm, M., Tuomilehto, J., Vanuzzo, D., Fenicia Vescio, F. (2003). Hypertension prevalence and blood pressure levels in 6 European countries, Canada, and the United States. JAMA, 289 (18), 2363-2369.

\section{KARDIOVASKULĀRO SLIMĪBU RISKA FAKTORU EPIDEMIOLOG̣ISKIE PĒTİJUMI LATVIJĀ PĒDĒJO 30 GADU PERIODĀ:}

KĀPĒC TIE IR NEPIECIEŠAMI?

Apskata mērḳis ir dot ieskatu par sirds un asinsvadu slimību (kardiovaskulāro) riska faktoru izplatības pētījumiem Latvijā galvenokārt pēdējo 30 gadu periodā. Apkopoti pētījumi pilsētvides, lauku reğionu un jauktās populācijās vecuma standartizētās kopās. To analīze parāda riska faktoru izplatības atškirības un kopējās likumsakarības dažādās vidēs. Kaut gan visos pētījumos tiek pierādīta augsta riska faktoru izplatība, vairums pētījumu jāuzskata par fragmentāriem, kuri aptver ierobežotas respondentu kopas. Iepriekšējo pētījumu analīze pamato valsts mēroga šḳērsgriezuma epidemioloǵiska pētījuma nepieciešamību, kas nelielā valstī ir veicams, ievērojot visas mūsdienu populācijas epidemioloğiska pētījuma prasības. 